\title{
Response of Broccoli Seedling to Some Plant Extracts
}

\author{
A. A. Mohsen ${ }^{(1)}$, M. A. Elhaak $^{(1) \#}$, M. A. AbdAlla ${ }^{(2)}$ and H.A. El Tanbashawy ${ }^{(2)}$ \\ ${ }^{(1)}$ Botany Department, Faculty of Science, Tanta University, Tanta and (2) Vegetation \\ Department, Horticulture Institute, Agricultural Research Center, Giza, Cairo, Egypt.
}

\begin{abstract}
A N EXPERIMENT was carried out on broccoli (Brassica oleracea L. var. Italica) during the winter seasons of 2014 and 2015 in Sakha Horticulture Research Station in Kafr ElSheikh Governorate under tunnels. The main objective of this study was to evaluate the effect of two aqueous extract concentrations (10\% and 20\%) of fresh leaves from basil (Ocimum basilicum) and eucalyptus (Eucalyptus camaldulensis) on growth the important medical and nutritional content of broccoli seedlings. The growth parameters of broccoli seedling significantly were increased by basil and eucalyptus leaf extracts particularly concentrations $10 \%$ of basil and eucalyptus. The fresh and dry weight of seedling root markedly increased. Also, stem length and leaf area of broccoli seedling were significantly increased. Broccoli seedlings photosynthetic pigments chlorophyll a, b and carotenoid contents were increased by most treatments especially by $20 \%$ basil extract. However, the ratio of $\mathrm{Chl}$. $(\mathrm{a}+\mathrm{b}) /$ carotenoid increased by higher value than the increase in the ratio of $\mathrm{Chl}$. a/b showing great antioxidant capacity due to treatment by the study extracts. In addition, the soluble protein and the sugars metabolism were markedly enhanced by different treatment of basil and eucalyptus leaf extracts. The important nutrients (nitrogen, phosphorous, potassium and calcium) absorption was increased by $10 \%$ of eucalyptus extract which was reflected on the plant growth. In general application of the two plants extract was important to achieve a vigorous seedlings that inshore great success of seedlings transplanting in the field.
\end{abstract}

Keywords: Brassica oleracea (broccoli), Aqueous extract, Ocimum basilicum, Eucalyptus camaldulensis, Pigments, Protein and sugars.

\section{Introduction}

Broccoli (Brassica oleracea L. var. Italica) is a member of the Brassicaceae (Decoteau, 2000). Broccoli stills grow in very limited scattered areas in Egypt although of its important feed and medical values (Abou El- Magd et al., 2006). Broccoli is an important medical plants as it is rich in both nutritional antioxidants; vitamins $\mathrm{C}$ and $\mathrm{E}$, and non-nutritional antioxidants; carotenoids, and phenolic compounds, particularly flavonoids which are seriously needed for liver diseases remediation (Michaud et al., 2002 and Lin \& Chang, 2005). Also Broccoli buds were found to be a rich source of most minerals especially of $\mathrm{K}$, $\mathrm{S}, \mathrm{P}$, and $\mathrm{Mg}$ in addition to some micro-elements (Aboul-Nasr \& Ragab, 2000). However, Broccoli prevents certain types of cancer, diabetes, heart diseases, osteoporosis, Alzheimer's disease, joint inflammation and high blood pressure (Chiu \& Houghton, 2005).
There is a concerted effort to search for naturally compounds from plants, because plants constitute a rich source of bioactive chemicals and many of them are largely free from harmful adverse side effects (Trojakova et al., 2001).

Basil (Ocimum basilicum L) is a member of the lamiaceae family. It is an aromatic herb that is used extensively to add a distinctive aroma and flavor to food (Javanmardi et al., 2002). Basil has been used as a medicinal plant in the treatment of headaches, coughs, diarrhea, constipation, warts, worms, and kidney malfunction (Simon et al., 1999). Also it has been demonstrated that aqueous Ocimum basilicum extract decreases plasma total cholesterol, LDL-cholesterol and triglycerides levels (Amrani et al., 2006). In addition basil has shown antioxidant and antimicrobial activities due to its phenolic and aromatic compounds (Gutierrez et al., 2008 and Hussain et al., 2008). Egyptian basil oil is similar to European basil

\#Corresponding author email: abdelhaakmah@yahoo.com 
oil (methyl chavicol; and to a lesser extent 1,8-cineole, alpha-pinene; ß-pinene; myrcene; ocimene; terpinolene; camphor; terpinen-4-ol; alpha-terpineol; eugenol; and sesquiterpenes). The major components of sweet basil oils from different origins were found to be linalool, eugenol, estragole and methyl cinnamate (Akgül, 1989 and Juliani \& Simon, 2002).

Eucalyptus is a tall and hard wood tree belongs to Myrtaceae. Its common names are River Red Gum, Murray Red Gum, Red Gum, and River Gum. Essential oils of various eucalyptus species are used in the pharmaceutical, toiletries, cosmetics, and food industries (Marzoug et al., 2011). These broad applications are due to the antiseptic, antihyperglycemic, antiinflammatory, flavor, and antioxidant properties of the molecules present in the oil (Takahashi et al., 2004). The strong antimicrobial activity of eucalyptus may be directly associated with their major compounds in the oil such as 1,8-cineole and $\alpha$-pinene (Elaissi et al., 2012). Putnam (1984) reported that eucalyptus species release volatile compound such as benzoic, cinamic and phenolic acids, which reduce the $\mathrm{pH}$ of soil enabling most soil nutrients absorption.

Bhandari et al. (1971) soaked Catharanthus roseus (Vinca rosea) seeds before sowing in 10, 20 and $50 \%$ aqueous extracts of Ocimum sanctum leaves. They found that internodes were shortened and the numbers of leaves increased. Also Nwachukwu \& Umechuruba (2001) noticed that seed germination and seedling emergence of yam bean seed were increased when seed soaked in aqueous leaf extract of basil.

El-Darier (2002) studied the effect of eucalyptus crude leaf powder and leaf water extract on growth and nutrient uptake of bean (Vicia faba L.) and maize (Zea mays L.). He found that the germination of two species was enhanced at $1 \%$ of eucalyptus leaf water extract and greatly reduced at $5 \%$. The shoot and root length and total dry weight were greatly reduced and both 1 and $5 \%$ of eucalyptus crude extracts enhanced the accumulation of $\mathrm{P}$ and $\mathrm{K}$, while $\mathrm{N}$ was not affected in bean. However, in maize $\mathrm{K}$ was increased, $\mathrm{N}$ dropped while $\mathrm{P}$ was not affected. Moreover, Niakan \& Saberi (2009) indicated that root and shoot lengths of Phalaris resulting from application of 5, 15 and 30\% concentration of aqueous extracts of eucalyptus leaf were significantly increased. Also, ElKaysi (2012) studied the effect of two extract concentrations $(5 \%$ and $10 \%)$ of eucalyptus on pea and found that, both treatments increased protein and carbohydrate percentages in seeds in comparison with the control plants. On other hand, chlorophyll content of Abutilon and Centaury was significantly reduced by enhancement of Sweet basil extract (Fanaei et al., 2013)

Hassannejad \& Ghafarbi (2013) carried out an experiment to assay the effects of different concentrations $(0,1.25 \%, 2.5 \%, 3.75 \%$ and $5 \%)$ of eucalyptus (Eucalyptus camaldulensis Dehnh.) on field dodder (Cuscuta campestris Yunck.) seed germination and seedling growth. They found that eucalyptus causes $12.05 \%$ increases in seed germination. In order these results, eucalyptus can be used in lowest concentration to stimulate field dodder seed germination for decreasing dodder soil seeds storage.

The aim of the present study is to evaluate the uses of fresh leaves extracts from basil (Ocimum basilicum) and eucalyptus (Eucalyptus camaldulensis) to produce vigor seedlings and improve the growth and nutritional quality of the important medical and nutritional broccoli vegetable plant.

\section{Materials and Methods}

The seeds of broccoli plant were obtained from the Agricultural Research Center, Ministry of Agriculture, Giza, Egypt. The seeds after sterilization by chlorox were soaked in two concentrations $(10 \%$ and $20 \%)$ of fresh leaves aqueous extract from basil (Ocimum basilicum) or eucalyptus (Eucalyptus camaldulensis). Aqueous extract were prepared by soaking of the plant leaves for $24 \mathrm{~h}$ in distilled water. Seeds were drilled in foam trays of 209 holes. The growing of seeds was repeated for two seasons. After 40 days from sowing the growth criteria of seedlings data were recorded. Seedlings shoot were dried at $70^{\circ} \mathrm{C}$ then grind in a Willy mill. The dry material nutrient elements were extracted by wet digested with mixture of sulphuric and percholoric acids as described by Allen et al. (1974).

\section{Growth parameters}

Samples of 7 seedlings were randomly chosen from each experimental plotto determine shoot and root fresh and dry weights (g), stem length 
(cm) and leaf area $\left(\mathrm{cm}^{2}\right)$. The water content of shoot and root was calculated from the fresh and dry weights.

\section{Photosynthetic pigments analysis}

The quantitative values of pigments (Chl. $\mathrm{a}, \mathrm{b}$ and carotenoids) were obtained by using absorption proposed by Welburn (1994).

\section{Estimation of total sugar and proteins}

The total sugars content in the seedling shoots dry materials was determined by colorimetric method according to Dubois et al. (1956). Total protein was calculated from total nitrogen percent multiplied by 5.7 (Knowels \& Watken, 1974).

\section{Nutrient elements content}

Total N, P and K (NPK) and Ca contents were determined according to the following methods. Total nitrogen was determined in the digestion product using the micro- Kjeldahl method according to AOAC (1980). Total phosphorus was determined colorimetrically by using a spectrophotometer according to Jackson (1967). Total potassium and calcium were measured using Atomic Adsorption Spectrophotometer, Perkin Elmer 3300.

\section{Statistical analysis}

Values in the results are represented as the mean and standard deviation $(\mathrm{M} \pm \mathrm{SD})$ for three replicates calculated by Microsoft excel. Analysis of variance (ANOVA) was applied for evaluating the significant of variances due to the used treatments and the differences between means were further tested using the Dunc's squire multiple range. All the statistical methods were as outlined by SAS (2004)

\section{Results}

\section{Growth criteria}

Data of Table 1 show that, the used treatments (10 and 20\% extract concentrations) of both basil and eucalyptus plants increased the shoot dry weight of broccoli plant significantly at the first and second seasons of study. The highest value of shoot dry weight was obtained by treatment with $10 \%$ eucalyptus extract followed $20 \%$ eucalyptus and $20 \%$ basil in comparison with the control at both seasons. The first treatment increased shoot dry weight by 15 and $19 \%$ at both seasons, respectively. The least effect was recorded by $10 \%$ basil.

The broccoli plant root dry weight (Table 1) indicated that all treatments had an increasing effect at both seasons. Treatment with $10 \%$ eucalyptus extract had the highest effect as it led to 29 and $38 \%$ increase in root weight compared with the control at the first and second season, respectively. The obtained differences were significant at both seasons. Also, the percentage increase of root dry weight by the previous treatment was greater compared with that of shoot.

Concerning broccoli plant stem length (Table 1), the used treatments increased the stem length and $20 \%$ basil extract led to the highest stem length followed by treatment with $10 \%$ eucalyptus extract compared to the control. The former treatment caused 13 and $10 \%$ increases in the stem length compared with the control at the first and second seasons, respectively. The differences obtained were significant at both seasons.

TABLE 1. The shoot and root dry weights $(\mathrm{g})$, stem length $(\mathrm{cm})$ and leaf area $\left(\mathrm{cm}^{2}\right)$ of treated broccoli plant by basil or eucalyptus extracts during 2014 and 2015 seasons.

\begin{tabular}{|c|c|c|c|c|c|c|c|c|c|}
\hline \multirow[t]{2}{*}{ Treatment } & & \multicolumn{2}{|c|}{$\begin{array}{c}\text { Shoot dry weight } \\
\text { (g) }\end{array}$} & \multicolumn{2}{|c|}{$\begin{array}{c}\text { Root dry weight } \\
\text { (g) }\end{array}$} & \multicolumn{2}{|c|}{ Stem length $(\mathrm{cm})$} & \multicolumn{2}{|c|}{ Leaf area $\left(\mathrm{cm}^{2}\right)$} \\
\hline & & 2014 & 2015 & 2014 & 2015 & 2014 & 2015 & 2014 & 2015 \\
\hline Control & & 0.079 & 0.078 & 0.017 & 0.016 & 4.96 & 4.98 & 4.84 & 4.61 \\
\hline Basil & $10 \%$ & 0.081 & 0.078 & 0.019 & 0.019 & 5.14 & 5.06 & 5.36 & 5.29 \\
\hline Basil & $20 \%$ & 0.086 & 0.084 & 0.021 & 0.021 & 5.62 & 5.49 & 5.71 & 5.52 \\
\hline Eucalyptus & $10 \%$ & 0.091 & 0.093 & 0.022 & 0.022 & 5.33 & 5.25 & 5.85 & 5.69 \\
\hline Eucalyptus & $20 \%$ & 0.085 & 0.086 & 0.021 & 0.018 & 5.11 & 5.14 & 5.54 & 5.34 \\
\hline F. test & & $* *$ & $* *$ & $* *$ & $* *$ & $* *$ & $* *$ & $* *$ & $* *$ \\
\hline $\operatorname{LSD}_{0.05}$ & & 0.005 & 0.004 & 0.003 & 0.001 & 0.091 & 0.05 & 0.153 & 0.118 \\
\hline
\end{tabular}




\section{Leaf area}

Broccoli plant leaf area data presented in Table 1 demonstrated that a significant increasing effect was achieved by the different extracts of the used plants. The greatest leaf area was obtained by treatment with $10 \%$ eucalyptus extract followed by treatment with $20 \%$ basil, while the lowest values were obtained by $10 \%$ basil at both seasons. There were 20 and $23 \%$ increases in the leaf area at the two seasons by the $10 \%$ eucalyptus extract.

In general, the inducement in the studied plant growth criterion was greater in the plants at the second season in comparison with those of the first one and by eucalyptus extract exhibited more inducing effect than similar concentration of basil extracts. It is also important to note that inducement was greater in the plant root dry weight followed by in the leaf area while the least inducement was in the plant stem length.

\section{Water content of shoot}

Data of Table 2 indicate that water contents of Broccoli plant shoot were decreased by treating with $10 \%$ and $20 \%$ of eucalyptus at the second season and of basil at the two seasons. Eucalyptus extract at the first season on the opposite increased shoot water content especially $20 \%$ which caused the highest content followed by $10 \%$ extract treatment. The differences were significant by the used treatment at both seasons.

The photosynthetic pigments

Data presented in Table 3 clear that all extract treatments increased chlorophyll a contents with significant values in both seasons. High values were obtained in response to basil extracts $(10 \%$ and $20 \%)$ as compared with values obtained by eucalyptus extract especially $10 \%$ which decreased chlorophyll a slightly. Also, all treatments increased the chlorophyll b content. Basil (20\%) caused the highest values and led to 37 and $35 \%$ increase over the control content in the two seasons, followed by eucalyptus extract $20 \%$ and basil $10 \%$. The obtained differences in chlorophyll b were significant and in both seasons of study. The obtained differences in the contents of carotenoids by the used treatments were significant in both seasons. The highest content was obtained due to eucalyptus $20 \%$ extract followed by those treated with basil $20 \%$ extract. The lowest obtained increases were by 15 and $14 \%$ in the two seasons by treatment with eucalyptus $10 \%$ extract.

The ratios of the different photosynthetic pigment to each other (Table 3) significantly varied in response to the utilized extract treatments in the two seasons of study. The ratio (chlorophyll $\mathrm{a} / \mathrm{b}$ ) decreased in comparison with that of control in response to the applied treatments especially by extract of basil $20 \%$. On the opposite, the data demonstrate that both treatments with basil (10\% and 20\%) and eucalyptus $(10 \%$ and $20 \%)$ increased the ratio of chlorophyll $(\mathrm{a}+\mathrm{b}) /$ carotenoid compared with control one. Higher values were obtained by extracts of basil especially $20 \%$.

TABLE 2. The shoot water content (\%) of treated broccoli plant by basil or eucalyptus extracts during 2014 and 2015 seasons.

\begin{tabular}{lccc}
\hline & & \multicolumn{2}{c}{ Water content of shoot (\%) } \\
\cline { 3 - 4 } Treatment & & $\mathbf{2 0 1 4}$ & $\mathbf{2 0 1 5}$ \\
\hline Control & 82.086 & 82.589 \\
Basil & $10 \%$ & 81.507 & 81.818 \\
Basil & $20 \%$ & 81.781 & 82.241 \\
Eucalyptus & $10 \%$ & 82.261 & 81.801 \\
Eucalyptus & $20 \%$ & 82.794 & 82.305 \\
F. test & & $* *$ & $* *$ \\
LSD $_{0.05}$ & & 0.081 & 0.051 \\
\hline
\end{tabular}


TABLE 3. The content (mg/g fr.wt.) of photosynthetic pigments (chlorophyll a, b and carotenoids) of treated broccoli plant by basil or eucalyptus extracts during 2014 and 2015 seasons.

\begin{tabular}{lcccccc}
\hline Treatment & & Ch. a & Chl. b & C. & Chl. a/Chl. b & Chl.(a+b)/C. \\
\hline Control & & 5.64 & 7.52 & 1.41 & 0.78 & 9.52 \\
Basil & $10 \%$ & 6.56 & 9.34 & 1.48 & 0.73 & 10.28 \\
Basil & $20 \%$ & 6.57 & 10.27 & 1.53 & 0.66 & 11.25 \\
Eucalyptus & $10 \%$ & 5.53 & 9.01 & 1.42 & 0.67 & 10.22 \\
Eucalyptus & $20 \%$ & 5.91 & 9.35 & 1.62 & 0.66 & 10.06 \\
F. test & & $* *$ & $* *$ & $* *$ & $* *$ & $* *$ \\
LSD ${ }_{0.05}$ & & 0.539 & 0.42 & 0.079 & 0.044 & 0.468 \\
\hline Control & & 5.88 & 7.43 & 1.34 & 0.75 & 9.13 \\
Basil & $10 \%$ & 6.33 & 9.12 & 1.42 & 0.71 & 10.22 \\
Basil & $20 \%$ & 6.26 & 9.99 & 1.46 & 0.61 & 10.83 \\
Eucalyptus & $10 \%$ & 5.34 & 8.77 & 1.32 & 0.65 & 10.57 \\
Eucalyptus & $20 \%$ & 5.93 & 9.14 & 1.53 & 0.63 & 10.78 \\
F. test & & $* *$ & $* *$ & $* *$ & $*$ & $* *$ \\
LSD & & & & & & \\
0.05 & & 0.113 & 0.236 & 0.058 & 0.084 & 0.443 \\
\hline
\end{tabular}

Data represented in Fig. 1 showed that the concentration of basil and eucalyptus extracts increased the total chlorophyll content and with greater values by eucalyptus than by basil. Total pigments were greater in the treated broccoli plants at 2014 season than in 2017 season but the opposite was true under control. The obtained differences were significant in both seasons.

\section{Total sugars and protein contents}

Data of Table 4 indicate that the treatments of both basil and eucalyptus increased the total sugar content in broccoli plants. The highest values were obtained by treating with $20 \%$ basil and $10 \%$ eucalyptus extracts, in comparison with the control in both seasons, respectively. The induced increases were significant in the first season but not significant in the second one. It is also remarkable that the increase in basil concentration induced more increase in sugars content, while the opposite was true for the increase in eucalyptus concentration attenuated the increase.

Protein content data (Table 4) clear that the used treatments increased protein content and the obtained differences were significant in both seasons. The highest content was induced by $10 \%$ eucalyptus extract treatment followed by $20 \%$ basil. Also, the increase in basil concentration induced more increase in protein contents, while the similar increase in eucalyptus concentration attenuated the increase in protein content markedly.

\section{Sugars/protein ratio}

The data of Table 4 clear that sugars to protein ratio in broccoli plant ranged between 6.6 to 8.4 and all of the used treatments decreased the sugar to protein ratio (S/P) except treatment by $10 \%$ basil extract which increased the ratio slightly compared with the control. On the opposite, $20 \%$ basil extract caused the least ratio. The obtained differences by both plant treatments were significant and in both seasons.

\section{The content of some nutrient elements}

The measured nitrogen, phosphorus and potassium (NPK) and calcium contents in the broccoli seedlings were significantly different under the effect of the used treatments of basil and eucalyptus extracts (Table 5). All of the used extracts induced greater uptake of the measured elements in comparison with the control. The 
highest contents of each nitrogen, phosphorus and calcium were obtained by $10 \%$ eucalyptus extract while that of potassium was obtained by $20 \%$ eucalyptus extract at both seasons. It was remarkable that eucalyptus extracts induced higher uptake of the tested elements compared with those of basil. Also, the increase in the elements ranged between a maximum of $22.5 \%$ and a minimum of $6.5 \%$ and the most increase was in nitrogen uptake.

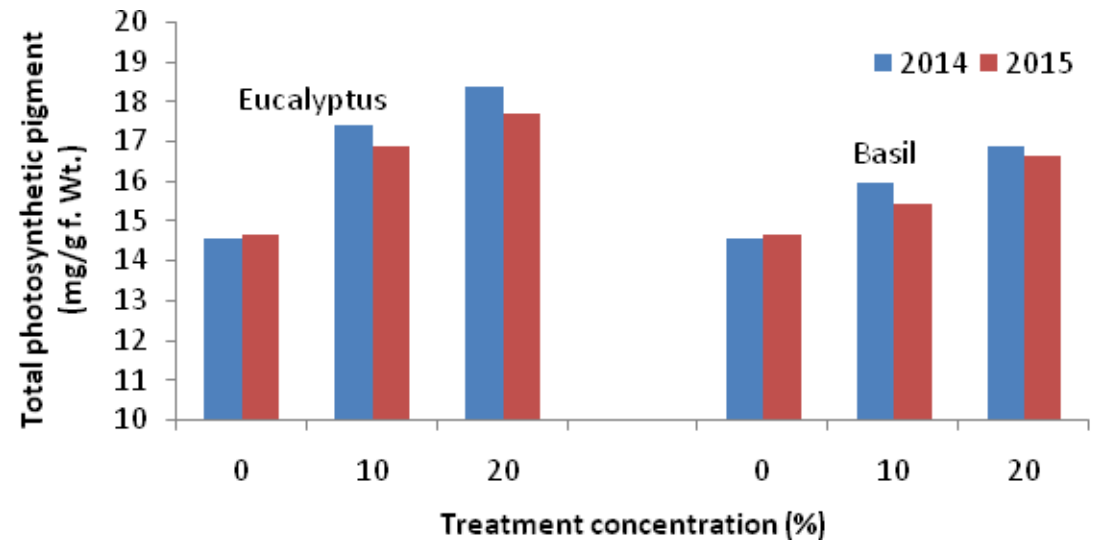

Fig.1. The total photosynthetic pigments (mg/g f. wt.) of treated broccoli plant by basil or eucalyptus extracts during 2014 and 2015 seasons.

TABLE 4. The protein, total sugar percentages and sugars to protein $(\mathrm{S} / \mathrm{P})$ ratio of treated broccoli plant by basil or eucalyptus extracts during 2014 and 2015 seasons.

\begin{tabular}{|c|c|c|c|c|c|c|c|}
\hline \multirow{2}{*}{ Treatment } & & \multicolumn{2}{|c|}{ Total sugar \% } & \multicolumn{2}{|c|}{ Protein \% } & \multicolumn{2}{|c|}{$\mathbf{S} / \mathbf{P}$} \\
\hline & & 2014 & 2015 & 2014 & 2015 & 2014 & 2015 \\
\hline Control & & 64.56 & 66.28 & 8.26 & 8.11 & 7.8 & 8.2 \\
\hline Basil & $10 \%$ & 67.56 & 68.22 & 8.26 & 8.14 & 8.2 & 8.4 \\
\hline Basil & $20 \%$ & 68.80 & 69.99 & 10.09 & 9.94 & 6.6 & 7.0 \\
\hline Eucalyptus & $10 \%$ & 68.21 & 70.62 & 10.24 & 10.09 & 6.7 & 7.0 \\
\hline Eucalyptus & $20 \%$ & 66.41 & 67.65 & 9.86 & 9.38 & 6.7 & 7.2 \\
\hline F. test & & $*$ & NS & $*$ & $*$ & $* *$ & $* *$ \\
\hline $\mathrm{LSD}_{0.05}$ & & 1.334 & & 2.53 & 1.575 & 0.801 & 0.714 \\
\hline
\end{tabular}

TABLE 5. The content of some nutrient elements (\%) of treated broccoli plant by basil or eucalyptus extracts during 2014 and 2015 seasons.

\begin{tabular}{|c|c|c|c|c|c|c|c|c|c|}
\hline \multirow{2}{*}{ Treatment } & & \multicolumn{2}{|c|}{ N\% } & \multicolumn{2}{|c|}{ P\% } & \multicolumn{2}{|c|}{ K\% } & \multicolumn{2}{|c|}{$\mathrm{Ca} \%$} \\
\hline & & 2014 & 2015 & 2014 & 2015 & 2014 & 2015 & 2014 & 2015 \\
\hline Control & & 1.48 & 1.42 & 0.149 & 0.156 & 5.47 & 5.41 & 1.28 & 1.24 \\
\hline Basil & $10 \%$ & 1.53 & 1.45 & 0.158 & 0.156 & 5.65 & 5.71 & 1.36 & 1.33 \\
\hline Basil & $20 \%$ & 1.74 & 1.69 & 0.161 & 0.162 & 5.77 & 5.75 & 1.27 & 1.30 \\
\hline Eucalyptus & $10 \%$ & 1.79 & 1.74 & 0.162 & 0.168 & 5.79 & 5.81 & 1.39 & 1.32 \\
\hline Eucalyptus & $20 \%$ & 1.73 & 1.63 & 0.154 & 0.151 & 5.99 & 6.04 & 1.29 & 1.24 \\
\hline F. test & & $* *$ & $* *$ & NS & $* *$ & $*$ & $* *$ & $*$ & $*$ \\
\hline $\mathrm{LSD}_{0.05}$ & & 0.081 & 0.17 & - & 0.008 & 0.284 & 0.212 & 0.07 & 0.059 \\
\hline
\end{tabular}




\section{Discussion}

It is cleared from the study data that the presence or application of basil and eucalyptus letters in the soil accelerated growth of broccoli because most growth parameters of broccoli seedling significantly increased with different treatment of basil and eucalyptus leaf extract particularly at concentrations 20 and $10 \%$ of basil and eucalyptus, respectively. These results indicate that seed germination stage of broccoli is less sensitive to allelochemicals produced by basil and eucalyptus leave extracts. However, the added allelochemicals and nutrient elements by the extracts of the two plants could have a beneficial role to the broccoli germination and growth. This appreciated presoaking of broccoli seeds in the two plants extracts at the used treatments for obtaining vigor seedling preparation for transplanting and better growth and productivity of the transplanted seedlings. These results agree with those obtained by Nwachukwu \& Umechuruba (2001) whom noticed that seed germination and seedling emergence of yam bean seeds were increased when seed soaked in aqueous leaf extract of basil. Moreover Durrani \& Prasad (2009) found that Ocimum canum plant extract have a stimulating effect on root weight of turnip. Also, El-Darier (2002) found that the germination of bean and maize was enhanced at low concentration of eucalyptus leaf water extract and reported that the stimulating effect of eucalyptus may be due to the allelopathic compounds such as fulvic, humic, and cinnamic acid released from eucalyptus and may be considered as promoters for the metabolic processes and seed germination if they occurred at a threshold concentration.

Moreover, Singh et al. (2006) reported that biological activities of receiver plants to allelochemicals are known to be concentration dependent with a response threshold. Responses are stimulation at low concentration of allelochemicals and inhibition as the concentration increases. In the present work, type and concentration of extract was critical in broccoli germination where all of the used treatments of the two plants insure a $100 \%$ of seed germination but the obvious effect of extract variation was remarkable on the germinated seedlings growth parameters. Treatments (10 and 20\%) of both basil and eucalyptus plants increased the shoot and root dry weigh of broccoli seedling significantly at the first and second seasons of study, especially the later which insure better nutrients and water uptake for the growing plants. The highest seedling shoot dry weight was obtained by treatment with $10 \%$ eucalyptus extract that increased shoot dry weight by 15 and $19 \%$ and root dry weight by 29 and $38 \%$ at both seasons showing greater percentage of increase in root than in shoot weight. This was reflected on the increase in broccoli plant stem length and leaf area, the latter increased by $20-23 \%$ compared with the control. Niakan \& Saberi (2009) indicated that root and shoot lengths of Phalaris resulting from application of 5,15 and $30 \%$ concentration of aqueous extract of eucalyptus leaf were significantly increased.

The photosynthetic pigments (chlorophyll $\mathrm{a}, \mathrm{b}$ and carotenoids) in leaves of broccoli seedling significantly increased in response to the used extracts of basil and eucalyptus even basil $(20 \%)$ caused 37 and $35 \%$ increasesin the chlorophyll $b$ content in the two seasons of study. The highest content of carotenoids was obtained due to eucalyptus $20 \%$ extract showing varied effect of the two plants extract on the different photosynthetic pigments. Eucalyptus extract induced carotenoids of antioxidant properties (Takahashi et al., 2004). The induced metabolism of the photosynthetic pigments signified the increased growth parameters by the used extracts. The ratios of the different photosynthetic pigment to each other were significantly altered in response to the utilized extract treatments of study which decreased the ratio chlorophyll $(\mathrm{a} / \mathrm{b})$ and chlorophyll $(\mathrm{a}+\mathrm{b}) /$ carotenoid compared with control one. The increase in total pigments content was greater by eucalyptus than by basil extracts confirming more importance for the former than the later plant extracts. In this response, Fanaei et al. (2013) found that chlorophyll content of Abutilon and Centaury significantly reduced by Sweet basil extract.

Basil and eucalyptus extracts induced significantly the metabolism of sugars in the germinated seedlings of broccoli with a highest value by treating with $20 \%$ basil and $10 \%$ eucalyptus extracts, in comparison with the control in the two seasons of study, respectively. These results were confirmed by El- Kaysi (2012) who found that carbohydrate percentages in pea seeds increased by sprayed with $5 \%$ and $10 \%$ of eucalyptus water extract. It is also remarkable that the response to basil was concentration dependence while, the opposite was true for eucalyptus extract which 
attenuated the increase in sugars. Similarly protein contentin broccoli seedlings increased significantly in both seasons. Remarkably, high contents were induced by $10 \%$ eucalyptus and $20 \%$ basil extract treatments. Also, the increase in protein contents was a function of increase in basil concentration but not a function of eucalyptus extract concentrations as higher concentration attenuated the increase in protein content markedly. The exhibited variations in sugars and protein in broccoli plant by all of the used treatments resulted in a decreased sugar to protein ratio $(\mathrm{S} / \mathrm{P})$ except treatment by $10 \%$ basil extract which increased the ratio slightly compared with the control. The results are in agreements with those reported by El- Kaysi (2012) who studied the effect of two extract concentration $(5 \%$ and $10 \%$ ) of eucalyptus on pea. He found that both treatments increased protein percentages in seeds in comparison with the control plants. The previous data confirmed soaking of broccoli seeds in the two plants extract especially low ones as they induced storage of sugars and proteins in seedlings which is critical for efficient seedlings transplanting in the field.

The total nitrogen, phosphorous, potassium (NPK) and calcium uptake by broccoli seedlings were increased by all of the used basil and eucalyptus extracts especially $10 \%$ eucalyptus extract which caused the highest percentages of $\mathrm{N}, \mathrm{P}$ and $\mathrm{Ca}$ in both season. Also the nitrogen, phosphorous and potassium content in broccoli seedlings was increased by increasing the concentration of basil extract. This may be attributed to the two plants extract induction of vigorous root system of treated broccoli seedling and hence higher mineral uptake of treated plants with basil and eucalyptus extracts. It is remarkable that eucalyptus extracts induced higher uptake of the tested elements compared with those of basil paralleling with the increase in root weight. Also, the increase in the elements ranged between a maximum of $22.5 \%$ and a minimum of $6.5 \%$ and the most increase was in nitrogen uptake. These results were confirmed by El-Darier (2002) who reported that 1 and $5 \%$ of eucalyptus crude leaf powder enhanced the accumulation of both $\mathrm{P}$ and $\mathrm{K}$, while $\mathrm{N}$ was not affected in bean.

\section{Conclusion}

It can be concluded from the findings that both extracts (basil and eucalyptus) have a stimulating effect on germination of broccoli seedling. The germination of broccoli was enhanced at a
$20 \%$ level of basil and $10 \%$ of eucalyptus water extract. The two plants extract activated sugars and nitrogen metabolism and NPK + Ca uptake in broccoli seedling which will be reflected on an efficient trans-plantation process. 1

\section{Reference}

Abou El- Magd, M.M., El-Bassiony, A.M. and Fawzy, Z.F. (2006) Effect of organic manure with or without chemical fertilizers on growth, yield and quality of some varieties of broccoli plants. J. Appl. Sci. Res. 2(10), 791-798.

Aboul-Nasr, M.H. and Ragab,W.S.M. (2000) Yield, head quality and nutritional composition of a new late flowering broccoli variety grown under Assiut conditions. Assiut Journal of Agricultural Science, 31(1), 55-77.

Akgül, A. (1989) Volatile oil composition of sweet basil (Ocimum basilicum L.) cultivating in Turkey. Nahrung. 33, 87-88.

Allen, S.G., Girmshaw, H.M., Parkinson, J.A. and Quarmby, C. (1974) "Chemical Analysis of Ecological Materials". Black Well Sci. Publ. Oxford, London. 565pp.

Amrani, S., Harnafi, H., Bouanani, N.H., Aziz, M., Serghini-Caid, H., Manfredini, S., Besco, E., Napolitano, M. and Bravo, E. (2006) Hypolipidaemic activity of aqueous Ocimum basilicum extract in acute hyperlipidaemia induced by triton WR- 1339 in rats and its antioxidant property. Phytotherapy Research, 20, 1040-1045.

AOAC (1980) "Official Methods of Analysis of Association of Official Analytical Chemists", $12^{\text {th }} \mathrm{ed}$. Washington, D.C

Bhandari, M.M., Mathur, J.R. and Sharma, H.C. (1971) Holy basil promotes flowering in periwinkle. Rajashtha Agriculturist Journal, 11, 1-14.

Chiu, B. and Houghton, P. (2005) Investigation of common vegetables for cholinesterase inhibitory activity, British Pharmaceut. Conf. 142 $2^{\text {nd }}, 9 / 26-$ 28/2005. pp.151.

Decoteau, D.R. ( 2000) "Vegetable Crops". Upper Rever Company. New Jersey, U.S.A.

Durrani, M.K.A. and Prasad, C. (2009) Allelopathic 
influence of basil extracts on Brassica rapa L.: II. Root weight and days to flower. J. Cruciferae Newsletter, 28, 34-36.

Dubois, M., Gilles, K.A., Hamilton, J.K., Rebers, P.A. and Fred, S. (1956) Colorimetric method for determination of sugars and related substances. Anal. Chem. 28, 350-356.

Elaissi, A., Rouis, Z.and Ben-Salem, N.A. (2012) Chemical composition of 8 eucalyptus species' essential oils and the evaluation of their antibacterial, antifungal and antiviral activities. BMC Complementary and Alternative Medicine, 12(81), 1-15.

El-Darier, S.M. (2002) Allelopathic effects of Eucalyptu rostrata on growth, nutrient uptake and metabolite accumulation of Vicia faba L. and Zea mays L. Pakistan Journal of Biological Sciences, 5(1), 6-11.

El-Kaysi, W.A. (2012) Effect of Aspirin spraying (acetyl salicylic acid) and extract of Eucalyptus incrassata on growth and yield of Pea (Pisum sativum L.). Journal of MadenatAlelem College, 4(1), 19-30.

Fanaei, M., Aboutalebi, A. and Mohammadi, S.A. (2013) Allelopathic effects of sweet basil (Ocimum basilicum) extract and essence on plantlet growth of three weed species. Intl. J. Agron. Plant. Prod. 4(4), 647-649.

Gutierrez, J., Barry-Ryan, C. and Bourke, P. (2008) The antimicrobial efficacy of plant essential oil combinations and interactions with food ingredients. Intl. J. Food Microbiol. 124, 91-97.

Hassannejad, S. and Ghafarbi, P.S. (2013) Allelopathic effects of allspice, eucalyptus, jujube, and persian walnut on field dodder (Cuscuta campestris Yunck.) seed germination and seedling growth. International Journal of Agronomy and Plant Production. 4(3), 442-449.

Hussain, A.I., Anwar, F., Sherazi, S. and Przybylski, R. (2008) Chemical composition, antioxidant and antimicrobial activities of basil (Ocimum basilicum) essential oils depends on season variations. Food Chem. 108, 986-995.

Jackson, M.L. (1967) "Soil Chemical Analysis". PrenticeHall of India, Private limited, New Delhi, pp. 115.

Javanmardi, J., Khalighi, A., Kashi, A., Bais, H.P. and
Vivanco, J.M. (2002) Chemical characterization of basil (Ocimum basilicum L.) found in local accessions and used in traditional medicines in Iran. Journal of Agricultural and Food Chemistry, 50, 5878-5883.

Juliani, H.R. and Simon, J.E. (2002) Antioxidant acitivity of basil. In: "Trends in New Crops and New Uses", J. Janick \& A. Whipkey (Ed.), pp. 575-579.

Knowels, F. and Watken, J.E. (1974) "A Practical Course in Agricultural Chemistry". Mac Millan and Co. Limited London.

Lin, C.H. and Chang, C.Y. (2005) Textural change and antioxidant properties of broccoli under different cooking treatments. Food Chemistry, 90, 9-15.

Marzoug, H.N.B., Romdhane, M. and Lebrihi, A. (2011) Eucalyptus oleosa essential oils: Chemical composition and antimicrobial and antioxidant activities of the oils from different plant parts (stems, leaves, flowers and fruits). Molecules, 16(2), 16951709.

Michaud, D.S., Pietinen, P., Taylor, P.R., Virtanen, M. Virtamo, J. and Albanes, D. (2002) Intakes of fruits and vegetables, carotenoids and vitamins A, E, C in relation to the risk of bladder cancer in the ATBC cohort study. Br. J. Cancer, 87, 960-965.

Niakan, N. and Saberi, K. (2002) Effects of eucalyptus allelopathy on growth characters and antioxidant enzymes activity in Phalaris weed. Asian Journal of Plant Sciences, 8(6), 440-446.

Nwachukwu, E.O. and Umechuruba, C.I. (2001) Antifungal activities of some leaf extracts on seed-borne fungi of African yam bean seeds, seed germination and seedling wmergence. J. Appl. Sci. Environ. Mgt. 5(1), 29-32.

Putnam, A.R. (1984) Allelopathic chemicals. Can natural plant herbicides help control weeds. Weeds Today, 15, 6-8.

SAS Institute, Inc (2004) SAS users Guide, Version 9.1 Statistical Analysis Systems Institute, Cary, NC.

Simon, J.E., Morales, M.R., Phippen, W.B., Vieira, R.F. and Hao, Z. (1999) A source of aroma compounds and a popular culinary and ornamental herb. In: "Perspectives on New Crops and New Uses", J. Janick (Ed.), pp. 499-505. 
Singh, H.P., Batish, D.R., Kaur, S., Arora, K. and Kohli, R.K. (2006) $\alpha$-Pinene inhibits growth and induces oxidative stress in roots. Ann.Bot. 98, 1261-1269.

Takahashi, T., Kokubo, R. and Sakaino, M. (2004) Antimicrobial activities of eucalyptus leaf extracts and flavonoids from Eucalyptus maculata. Letters in Applied Microbiology, 39(1), 60-64.

Trojakova, L., Reblova, Z., Nguyen, H.T.T. and Pokorny, J. (2001) Antioxidant activity of rosemary and sage extracts in rapeseed oil. Journal of Food Lipids, 8, 1-13.

Welburn, A.R. (1994) The spectral determination of chlorophylls a and b, as well as total carotenoids, using various solvents with spectrophotometers of different resolution. J. Plant Physiol. 144, 307-313.

(Received 15 / 1 / 2017; accpted 19 / 2 / 2018)

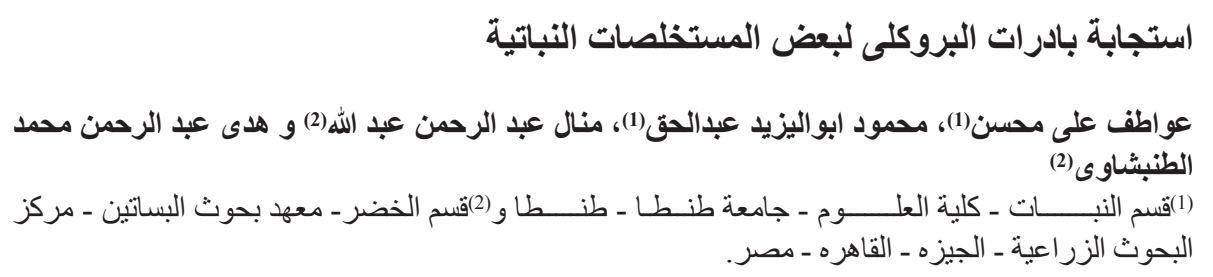

أجريت تجر بتين على بادر ات البروكلى (Brassica oleracea L. var. Italica) خلال موسمين الثتاء 2014

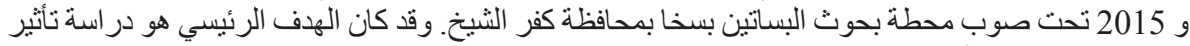
المستخلص المائي لأوراق الريحان (Ecimum basilicum) و الكافور (Eucalyptus camaldulensis)

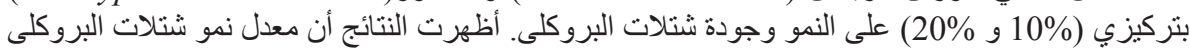

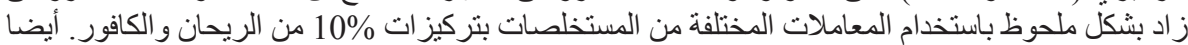

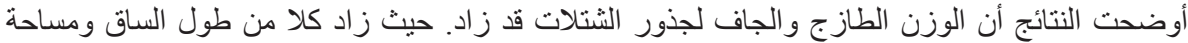

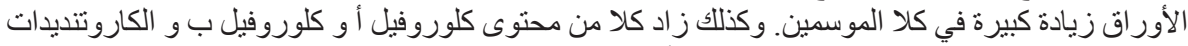

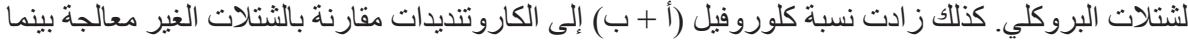

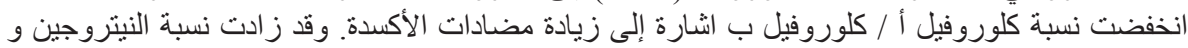

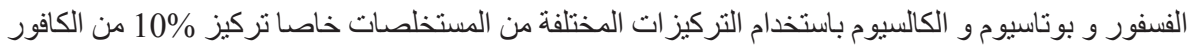

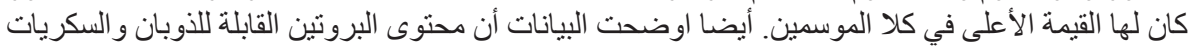

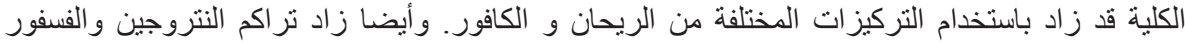

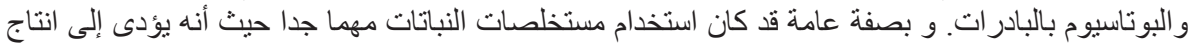

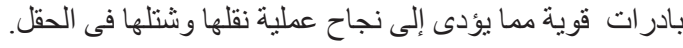

